\title{
Faktitivní porucha
}

\author{
MUDr. Birgita Slováčková, Ph.D.', Mgr. Rastislav Žirko', doc. MUDr. Ladislav Slováček, Ph.D. ${ }^{2}$ \\ ${ }^{1}$ Psychiatrická klinika, Fakultní nemocnice a Lékařská fakulta UK Hradec Králové \\ ${ }^{2}$ Ordinace praktického lékaře pro dospělé, Poliklinika IV Hradec Králové
}

U faktitivní poruchy pacient předstírá příznaky, agravuje nebo se sebepoškozuje. Na rozdíl od simulace to nedělá z vědomě zištných důvodů. Primárním cílem je získat lékařskou péči a zájem druhých. Autoři ve svém sdělení popisují prípad mladé ženy s projevy závažné faktitivní poruchy. Poukazují na složitost přesnější diagnostiky u nemocných s rozmanitými či závažnými somatickými př́znaky, které nejsou dostatečně vysvětlitelné současnými medicínskými postupy.

Klíčová slova: faktitivní porucha, medicínsky nevysvětlitelné příznaky.

\section{Factitious disorder}

For a factitious disorder, the patient pretends to be symptomatic, aggravates, or self-inflicted. Unlike the simulation it does not do it for consciously good reasons. The primary goal is to get medical attention and interest in others. The authors describe the case of a young woman with serious facial disorder. They point to the complexity of more accurate diagnostics in patients with multiple or severe somatic symptoms that are not sufficiently explained by current medical practices.

Key words: factitious disorder, medically unexplained symptoms.

\section{Úvod}

Konziliární psychiatr bývá na somatická oddělení zván k pacientům, kteří mají rozmanité či přetrvávající tělesné obtíze, pro které lékaři nenacházejí odpovídající organopatologický korelát. Organické patologické změny bud' chybějí zcela nebo dostatečně nevysvětlují intenzitu, povahu či rozsah příznaků. Medicínsky nevysvětlitelné príznaky jsou závažným problémem ve zdravotnictví. Z psychiatrického hlediska se obvykle jedná o nemoci ze spektra somatoformních poruch (dále jen SP), faktitivních poruch (dále jen FP) a simulace. $V$ klinické praxi tyto poruchy patři mezi nejsložitější fenomény. Jsou obtížně diagnostikovatelné i léčebně ovlivnitelné. U SP dochází k tvorbě príznaků nevědomě a mimovolně. U simulace je to výlučně vědomé a volní, a to ze zištných důvodů. FP mají místo někde uprostřed. Pacient vědomě předstírá přiznaky, agravuje nebo se sebepoškozuje. Motivace k to- muto chování může být nevědomá. Primárním cílem u FP je získat péči a zájem zdravotníků, soucit, pozornost a podporu druhých. Velmi často jde o uspokojení potřeby závislosti na druhých u zranitelných osob se závislou či hraniční poruchou osobnosti. U těchto pacientů dochází k více či méně vědomému „útěku do nemoci", ze kterého plyne určitý zisk. Pacienti trpící těmito poruchami značně psychicky strádají a ztráty z nemoci významně převažují nad zisky. Dochází k nadměrné spotřebě medicínské péče, významné morbiditě a mortalitě, zejména díky nesprávným léčebným prístupům (1). Podle prevažující symptomatiky se předstírané poruchy dělí dle diagnostických kritérií na poruchy se somatickými príznaky, psychickými príznaky a smíšenými príznaky. Ze somatických príznaků pacienti nejčastěji předstírají náhlé př́hody břišní, krvácení, křeče, bolesti. Dalším typem je FP by proxy, kdy dochází k volní produkci př́znaků tělesné či psychické poruchy u jiné osoby, kterou má dotyčná osoba v péči (2). Nejznámějším obrazem FP je Münchhausenův syndrom, kde kromě předstírání príznaků dochází k bájivé Ihavosti a putování po zdravotnických zařízeních. Častější projevy FP jsou ale méně nápadné, objevují se u mladých žen s nedostatečnou podporou rodiny, chovají se pasivně, nezrale a mají řadu hypochondrických rysů (2). Faktitivní poruchy jsou spojeny s osobnostními nápadnostmi. V extrémním případě mohou vést $k$ drastickému sebepoškozování a zbytečným operacím $(3,4)$. Sebepoškozující chování lze rozdělit do třech typů (2): 1. prrímé (škrábání, řezání, bodání), 2. sebeindukující (použití poškozující medikace či infekčních látek), 3. delegované (operace, amputace či jiné vysoce rizikové terapeutické nebo diagnostické postupy). V anamnéze těchto pacientů se často setkáváme s citovou deprivací a odmítáním
KORESPONDENČNÍ ADRESA AUTORA: MUDr. Birgita Slováčková, Ph.D., slovackovab@lfhk.cuni.cz Psychiatrická klinika, Fakultní nemocnice a Lékařská fakulta UK Hradec Králové

Sokolská 581, 50005 Hradec Králové
Cit. zkr: Psychiatr. praxi 2018; 19(1): 35-38

Článek príijat redakcí: 22. 1. 2018

Článek přijat k publikaci: 15. 2. 2018 


\section{VONZILIÁRNÍ PSYCHIATRIE}

\section{FAKTITIVNÍ PORUCHA}

ze strany rodičů, zneužíváním či ztrátou rodičů $v$ dětství (2). Anamnestické údaje podávané pacienty jsou často inkonzistentní. Pro stanovení diagnózy je nutno získat informace z více zdrojů (od předchozích lékařů, zdravotníků, rodinných př́slušníků). Objektivizace pacientovy životní a sociální situace je mnohdy obtížná. Někdy je potřebné i kontinuální sledování pacienta v nemocničním prostředí. Faktitivní porucha obvykle začíná v dospělém věku mezi 20.-40. rokem, někdy i dríve. Klinický průběh může být akutní či chronický (2). U chronických případů dochází k četným návštěvám lékařů, dlouhodobým či opakovaným hospitalizacím. Pacienti bývají léčeni "symptomaticky“, bývají operováni, invazivně vyšetřováni, což je zbytečně ohrožuje. Odhalení skutečné diagnózy vede u zdravotnického personálu k negativním protipřenosovým reakcím. Léčba je v současnosti nedostatečná, prognóza nepř́znivá (1). Psychiatrickou péči obvykle tito pacienti odmítají. Konziliární psychiatr by měl zdravotnickému personálu vysvětlit charakter poruchy a protipřenos. Pacient by měl být se zjištěnou psychopatologií v klidu konfrontován bez moralizování a hněvu $(2,5,6)$. Ke zmírnění symptomatiky mưže vést podpưrná psychoterapie. Další psychoterapie by se měla odvíjet od osobnostních rysů pacienta (3-5). Somatičtí lékaři by se měli snažit snižit počet invazivních a potencionálně rizikových diagnostických a léčebných procedur. V současné době nemáme dostatek informací nutných ke kritickému zhodnocení efektivity jakékoliv terapie FP (7).

\section{Popis př́ípadu}

S 36letou pacientkou jsem se setkala na konziliárním psychiatrickém vyšetření za hospitalizace na II. interní gastroenterologické klinice Fakultní nemocnice Hradec Králové (dále jen FN HK) v červnu roku 2015, kde byla vyšetřována pro enteropatii. Již tehdy se léčila pro řadu závažných somatických nemocí. V kontaktu vystupovala společensky, byla vitální a statečně bojující se svými onemocněními a nepř́iznivou životní situací. Nebyla nijak úzkostná ani depresivní. V žádosti o psychiatrické konzilium stálo: „prosím o návrh úpravy chronické farmakoterapie s ohledem na management terapie bolesti". Při mém podrobnějším dotazování ošetřujícího lékaře pacientky na lůžkovém oddělení jsem se dozvěděla, že mezi lékaři, kteří mají pacientku v péči, opakovaně probíhá diskuze a úvahy o korelaci subjektivních obtíží a jejich organickým podkladem. Lékaři již řadu let zvažovali psychogenní podklad obtiží s ohledem na anamnézu týrání pěstouny v dětství. Pacientku jsem psychiatricky vyšetřila a posléze jsem doporučila i psychologické přešetření. Následně jsem podrobně prostudovala její zdravotní dokumentaci vedenou v našem zdravotnickém zařízení. Bylo to poměrně náročné, protože $\checkmark$ té době již byla pacientka v péči nebo byla vyšetřena v mnoha specializovaných ambulancích (ambulance léčby bolesti, revmatologická poradna, imunologická ambulance, koloproktologická poradna, neurologická ambulance, gastroenterologická ambulance, ortopedická ambulance, psychiatrická ambulance, neurochirurgická a rehabilitační ambulance). Pacientka byla též v našem zdravotnickém zařízení opakovaně hospitalizována.

Pacientka byla od časného dětství opakovaně adoptována, biologická matka ji odložila. $\checkmark$ deseti měsících věku utrpěla trauma hlavy. Dle dostupné zdravotnické dokumentace se jednalo o epidurální a subdurální hematom. Sama z tohoto údaje usoudila, že byla týrána. S adoptivní rodinou (rodiči a sourozenci), která ji vychovávala od jejích 2 let, se nestýká. Je vyučená dámskou krejčovou. Krátce pracovala jako švadlena, pak jako uklízečka. Od svých dvaceti pěti let věku byla v částečném invalidním důchodu a od dvaceti šesti let věku pak v plném invalidním důchodu pro pohybové obtíže. Ve svých třiceti letech věku byla dva měsíce vdaná, ale manžel ji dle jejích slov týral, takže se rozvedli. Ale dle údajů od manžela ve zdravotní dokumentaci z tehdejší doby na něj byla opakovaně agresivní, ponižovala ho. Od té doby žije sama v bezbariérovém bytě, jen s kočkou. Stará se o ni pečovatel - dobrovolník, sedmdesátiletý pán, o kterém říká, že je moc hodný. Sama pacientka uvádí, že s domácími pečovatelskými službami má negativní zkušenosti z minulosti. Sděluje: „ty holky mě začaly obviňovat, že si z nich dělám služky". V naší psychiatrické ambulanci byla pacientka $v$ minulosti vyšetřena dvakrát. Poprvé v době svého krátkého manželství, tj. ve třiceti letech věku, po konfliktu s manželem, kdy měla suicidální proklamace. Pak za dva roky pro anxiózní syndrom po konfliktu a rvačce s nevlastní sestrou. V obou př́padech šlo o situační záležitost nevyžadující psychofarmakologickou terapii či jinou psychiatrickou intervenci. Zachyceny byly její osobnostní emočně nestabilní rysy.

Svou kariéru pacientky započala v době časného dospívání. Od deseti let věku měla bolesti kyčlí, které se od patnácti let věku zvýraznily a od šestnácti let věku chodila s francouzskými holemi. Sama uvádí, že lékaři si nevěděli s jejími obtížemi rady, nakonec to nazvali „Iupavými kyčlemi“. V devatenácti letech věku absolvovala korekční operaci (dle dostupné zdravotnické dokumentace se jednalo o protětí tractus iliotibialis). Dále ale chodila s francouzskými holemi a ve svých dvaceti sedmi letech věku skončila na elektrickém vozíku, na kterém je dosud. Sama uvádí, že chůzí o berlích si zničila ruce (dle dostupné zdravotnické dokumentace diagnosticky uzavíráno jako útlak nervus ulnaris vpravo) a vyústilo to také v operaci.

Ještě před osmnáctým rokem věkem si stěžuje na rưzné trávicí obtíže a ve dvaceti jedna letech věku jí byla stanovena diagnóza celiakie. $\checkmark$ dalších letech byla gastroenterologem vedena jako autoimunitní enteritida (autoprotilátky specifické pro celiakii opakovaně neprokázány). Od dvaceti šesti let věku se u pacientky stupňují bolesti břicha a poruchy vyprazdňování (střídání průjmů a zácpy). Ve třiceti dvou letech věku se vytvořil anální absces s nutností incize a drenáže, rok na to perianální pištěl s nutností operace. Pro bolesti břicha a obtíže s vyprazdňováním je během těchto let opakovaně hospitalizována v našem zdravotnickém zařízení. V její zdravotnické dokumentaci je dále uváděna polyvalentní léková a potravinová alergie, ale kožní potravinové testy jsou opakovaně negativní, stejně tak i opakované precipitace na užívané léky. Její jídelníček je velmi omezen. Od svých třiceti třech let věku jí dle svých slov téměř výlučně Nutridrinky, pomerančový džus a občas holé kuřecí maso. I za hospitalizace na somatickém oddělení odmítá jiná dietetická opatření a zhodnocení tolerance potravin s tím, „že to $v$ minulosti k ničemu nevedlo". V té době již užívá na "kruté bolesti břicha, zad a kloubư" injekce morfinu. Při snaze o vysazení morfinu za hospitalizace je prítomen abstinenční syndrom. Při převedení na opiátové náplasti (transdermální fentanyl) uvádí intoleranci, stejně tak u jiných analgetik. Přestože byla řádně algeziologem poučena o možnostech analgetické terapie a rizikovosti současné léčby, jinou analgetickou medikaci striktně odmítá. Požaduje ponechat 
medikaci morfinem subkutánně s frekvencí aplikace 3-4x denně, což jí dlouhodobě vyhovuje a nenaléhá na navyšování dávky. Pacientka si radu let aplikuje klyzmata a sama si manuálně vybavuje stolici. Z důvodu inkontinence stolice, která ji obtěžuje mezi lidmi, nosí pleny. V posledních letech však dochází pouze k lékařům, jinam do společnosti nechodí. Klyzma jí údajně alespoň o polovinu snízí pravděpodobnost, že se někde pokálí. Zkoušela různé typy plen, po některých má „boláky a červený zadek jako pavián". S kožními afekcemi dochází do imunologické ambulance. Dle dostupné zdravotnické dokumentace hodnoceno jako recidivující kožní infekce, léčba bakteriální autovakcínou byla bez efektu. Pacientka lékařům opakovaně zdůrazňuje, že si opakovanou aplikací klyzmat úplně zničí ruce - „že by se ráda těma rukama alespoň za pár let napila z hrníčku“. Lékaři je tedy $v$ jejích třiceti šesti letech věku navrženo provedení sigmoideostomie, jedná se ale spiše o žádost nemocné. Lékaři si od tohoto zákroku slibují zvýšení kvality života pacientky. V témže roce je pacientce provedena subtotální kolektomie a terminální transversostomie. Medicínským důvodem operace je funkční porucha GIT, snížená funkce rekta, insuficience análního svěrače. Do třech týdnů po operaci došlo k dehiscenci pahýlu rekta a rozvoji pneumoperitonea. Stav byl řešen konzervativně (systémová antibiotika a rektální drenáž). Za necelý rok došlo k prolapsu pahýlu rekta, chronickému abscesu malé pánve a prolapsu stomie. Byla provedena laparoskopická extirpace pahýlu s revizí stomie. Pacientka si stomii ošetřuje sama, denně si do ní aplikuje miniklyzmata, jinak se by se cítila „plná“. I po operaci prolapsu pacientka přesto udává, že má opět prolaps pět až deset centimetrů, který si volně reponuje zpět. Lékař ho ale nepozoruje, nicméně za několik měsíců je ve zdravotnické dokumentaci popisován prolaps stomie tři až pět centimetrů. Pacientka je opětovně hospitalizovaná na interním oddělení pro trávicí obtíže, nevolnosti a bolesti břicha, které trvají dosud. Užívá laxativa a aplikuje si morfin 3-4x denně. Hmotnost je v posledních letech nízká, nicméně stabilní, BMI je 17,7.

Při psychiatrickém vyšetření, jehož okolnosti jsou uvedeny výše, byla pacientka v lůžku, lucidní, orientovaná kompletně správně, v kontaktu společenská, ochotně spolupracující, sdílná, emočně živá, klidná, usměvavá, nálada bez patologie, hedonie zachována, zájmy omezeny, myšlení souvislé, centrované na somatické obtiže, psychotické př́iznaky nezjištěny. Sekundární insomnie při bolestech, syndrom neklidných nohou, restrikce príjmu jídla, tělesný dyskomfort príi chronickém algickém syndromu, fyzické limity, osobnost traumatizovaná z dětství. Magnetická rezonance mozku provedená v roce 2013 byla s normálním nálezem. Z psychiatrického vyšetření vyplývá, že by se mohlo jednat o FP či SF. Následovalo provedení psychologického vyšetření, které zahrnovalo rozhovor s pacientkou se zaměřením na současné potíže, aktuální zdravotní stav i celkovou životní situaci. Dále bylo zadáno k vyplnění inventorium MMPI-2 a v závěru byl administrován Rorschachưv test. Z testových metod je patrné, že schopnost a ochota samostatné orientace $v$ problematice je malá. Kognitivní flexibilita je nízká (naopak rigidně trvá na svých názorech a drží se svých zjednodušených představ). Osobnost je nezralá, s rysy závislosti, infantilně požadovačná, manipulující se svým okolím. Vysoká je pohotovost k opozičním reakcím i konfrontaci, emočním rozladám až dysforii. Nelze vyloučit hraniční poruchu osobnosti. Z psychologického vyšetření celkově vyplývá, že pacientka dlouhodobě nerozviji žádnou ze svých životních rolí, kromě role pacienta, a sama o sobě také mluví jen z této perspektivy. Role nemocné je pro ni i určitým aktivním seberealizováním (kariérou či cestou k „výjimečnosti“, sociálním kontaktům, podpoře i péči okolí). Utrpení se nejeví dominující v prožívání pacientky ani v jejích verbalizacích (svưj úděl se snaží nést statečně). Lze zvažovat poruchu osobnosti hraničního typu, prítomný je ale i výrazný průnik symptomatiky psychiatrem zvažovaného kontinua: SF - FP. Lékaři byli o závěrech psychiatra i psychologa ústně informováni včetně širších souvislostí a rizik. Pacientka byla seznámena s tím, že v jejích tělesných obtižích hrají významnou roli její osobnostní charakteristiky a neprijiatá traumata z dětství. To pacientka striktně odmítla, stejně tak nabídku psychiatrické péče.

\section{Diskuze}

Diferenciálně diagnosticky lze u naší pacientky zvažovat některou z forem SF: 1. somatizačníporucha - obtíže jsou nápadné, měnlivé a dramatické, z více orgánových systémů, pacientka se je snaži řešit i za cenu invazivních vyšetření 


\section{VONZILIÁRNÍ PSYCHIATRIE}

a zbytečných operačních výkonů. 2. somatoformní vegetativní dysfunkce - $v$ prípadě naší pacientky dráždivý tračník. Významné je v této souvislosti pacientkou uplatňované zajištující a vyhýbavé chování (klyzmata, restrikce jídla apod.), které jí mají v jejích obtížích ulevit, ale ve skutečnosti dále výrazně prohlubují symptomatiku. 3. Ize diferenciálně diagnosticky zvažovat přetrvávajícíbolestivou poruchu. Zpočátku se bolest týkala kyčlí, během let se ale rozširíila i na záda a kořenové i drobné klouby. Dalším zdrojem bolestí jsou křeče v břiše, které pacientka udává na škále bolesti 0-10 na čísle 7, někdy 10-11, což vedlo lékaře k nasazení silného potentního opioidu morfinu.

Celkově diagnostiku SF u pacientky pokládám za méně pravděpodobnou zejména z důvodu, že nevysvětluje symptomatiku v celé širíi a dále je neprítomen emoční dyskomfort, který je u SP vedle nevysvětlitelných somatických príznaků hlavním projevem. Diagnóza simulace je u pacientky nepravděpodobná. Invalidní důchod získala před řadou let a od té doby své příznaky dále mohutně rozvijij. Žádné jiné zjevné zevní cíle nebyly zachyceny. Diagnózu FP bych u pacientky zvažovala z několika důvodů: 1. inkonzistence a nepravdivost anamnestických údajů. 2. nejasnost a nepotvrzenost řady diagnóz - např́klad potravinová a léková alergie, která dostupnými metodami nebyla potvrzena a vznikla na základě stesků pacientky, tj. vyrážka, křeče v břiše, otoky. Nejasnost je i kolem recidivujících afekcí na nohou, zádech, hýždích, jejichž léčba imunoterapií byla bez efektu. 3. rozsah

\section{LITERATURA}

1. Grambal A, Grambalová Z, a kol. Veš špitální - faktitivní poruchy a simulace $v$ psychiatrické péči. Psychiat. ro Praxi 2010; 11(4): 164-166.

2. Praško J, Seifertová D. Předstírané poruchy a simulace. Med. Pro Praxi 2008: 5(3): 128-132.

3. Urban A, Masopust J. Münchhausenův syndrom. Psychia- zajištujícího a vyhýbavého chování týkající se jak trávicího traktu, tak pohybového aparátu. Restrikce jídla, vyhraněná dietní opatření, zneužívání laxativ, nadužívání klyzmat a manuálního vybavení stolice, což vedlo k vytvoření abscesu, pištěle, narušení funkce rekta a insuficienci análního svěrače. Po provedení stomie si do ní aplikuje miniklyzmata, což opakovaně vede k jejímu prolapsu. Holemi a klyzmaty je pretěžována zejména pravá horní končetina, došlo k útlaku nervus ulnaris vpravo. Imobilita vedla k rozvoji syndromu dekondice, bolestem dolních končetin i zad. Dolní končetiny jsou atrofické, s omezenou hybností. 4. předstírání přiznaků: v roce 2014 hospitalizována na chirurgické klinice pro podezření na mechanický ileus, provedeným RTG a CT břicha toto nepotvrzeno, následně pacientka tentýž den odchází na negativní reverz. 5. prímé sebepoškození: v roce 2015 si pacientka sama provedla punkci v oblasti pravého kolene. 6. delegované sebepoškození - Ize zvažovat již od její první operace, tj. korekční operace kyčlí. Dále operace pravého loketního kloubu, operační ošetření perianálního abscesu, píštěle, provedení stomie, reoperace stomie i pahýlu rekta. K delegovanému sebepoškození Ize jistě připočítat i parenterální aplikaci morfinu. 7. manipulativní chování, kterým pacientka dosahuje dalších vyšetření, léčebných zákroků, dalších diagnóz, vše s nutností návštěv specialistư či hospitalizací. 8. role nemocné je jediným zjištěným ziskem.

V našich diagnostických úvahách může napomoci i „historka“" z poslední doby, kdy pacient-

tria Pre Prax 2004; 2: 59-63.

4. Rahn E, Mahnkopf A. Psychiatrie: učebnice pro studium a praxi. Praha: Grada 2000: 466 s.

5. Serranová T, Růžička E, Roth J. Funkční poruchy hybnosti. Cesk Slov Neurol N 2014; 77/110(3): 270-286.

6. Edwards MJ, Bhatia KP. Functional (psychogenic) move- ka prijiela do žurnální služby Psychiatrické kliniky FN HK s cílem „pokecat si“ s lékařkou. Přijela na vozíku (hand bike), který byl výrazně vyzdoben rozmanitými vlaječkami. Na klíně měla kočku na vodítku, ta má na sobě rưžový obleček i s kapucí na hlavě, aby „neprochladla“. Mimo jiné sděluje, že sertralin nyní dává kočce, „aby neměla nervy”. Kočce nyní také musela koupit elektrické WC za několik tisíc, aby měla příjemnější vyprazdňování, kočka má totiž taky zažívací obtí̌e... což imponuje až jako FP by proxy.

\section{Závěr}

Tento prípad poukazuje na složitost přesnější diagnostiky u pacientů s rozmanitými či závažnými somatickými př́znaky, které nejsou dostatečně vysvětlitelné současnými medicínskými postupy. Somatičtí lékaři tuší „psychickou nadstavbu", přesto pacienta dále vyšetřují a rozšiřuji seznam nemocí, o jejichž správnosti lze ale při bližším prozkoumání pochybovat. Přesto se využívají invazivní a rizikové metody diagnostiky i léčby, které ve svém důsledku pacienta dále poškozují. Psychiatr je mnohdy povolán až v pokročilém stadiu poruchy, kdy již není možné účinně terapeuticky zasáhnout a změnit trajektorii vývoje. Prípad této pacientky vnímám jako medicínské selhání. Pokud ho bylo možno zvrátit, pak dle mého názoru v časných stadiích poruchy, tedy $v$ době mezi 17. a 19. rokem věku, optimálně ještě před první operací. Ve své klinické a konziliární praxi bychom měli na toto spektrum diagnóz více myslet včetně edukace somatických lékařů o této problematice.

ment disorders: merging mind and brain. Lancet Neuro 2012; 11(3): 250-260.

7. Eastwood S, BissonJl. Management of Factitious Disorders: A Systematic Review. Psychother Psychosom 2008; 77: 209-218. 